\title{
Erosion of Moral Ethics among Military Personnel
}

\author{
Dr. Priyanka Tiwari ${ }^{1}$,Dr. Sakshi Mehrotra ${ }^{2}$ \\ Amity Institute of Psychology and Allied Sciences, Amity University, Noida, India
}

\begin{abstract}
The study examines the issue of moral ethics among military personnel. Military is the core component of a country. Country maintains its military in order to safeguard their core values and national interest from external aggression and internal subversion. The military personnel come from the same society where erosion in the value system is constantly taking place from various reasons. Consequently it is difficult for military personnel to remain completely immune to these corrupting influences. The present study focuses on the erosion of moral ethics in our savior. The research was carried on the basis of both primary and secondary sources and the result was analyzed accordingly. The study revealed that erosion is more at senior level and personnel are not free to talk about such incidence officially. It is acting like a termite among personnel. Article will also focus to propose some suggestive measures in this regards.
\end{abstract}

Keywords: Moral, Ethics, Military Personnel

\section{INTRODUCTION}

The Indian classic Gita symbolizes true Indian culture, particularly the ethics of soldiering. The concern is with action alone and not with the result thereof. When one does his duty as worship, there is no question of seeking appreciation or fearing condemnation. Work done as duty will bring no frustration. Thus the essence of duty is desire-less action. The eternal lesson from Gita for a soldier is 'duty unto death'. Lord Krishna conjures up Arjuna by reiterating, "Lucky are those soldiers who die for the righteous cause." $\mathrm{He}$ exhorts, "Slain, thou shall go to heaven, victorious thou shall enjoy the earth. According to Gita, "To him who has conquered himself, his own self is a friend, but to him who has not conquered himself, his own self is hostile like an external enemy". Ultimately, what help a man to attain the valued ethics are austerity, self-control and renunciation. In the Upanishads the body is compared to a chariot, the embodied soul to its master, the intellect or discriminative faculty to the driver, the mind to the reins, the senses to the horses, and sense objects to the roads. The chariot can take the master to his destination if it is strongly built, if the driver can discriminate between the right and wrong road, if the reins are strong, the horses effectively controlled, and if the roads are well chosen. Before proceeding ahead it is important to know what is Moral ethics, military force, who are the military personnel and how there is erosion of moral ethics among military personnel?

\subsection{Moral ethics}

Morals define personal character, while ethics stress a social system in which those morals are applied. In other words, ethics point to standards or codes of behaviour expected by the group to which the individual belongs.

Moral ethics can be defined as those principles on which our moral decisions are based. Ethics are the sense of right and wrong, good and evil, values and responsibility. It can be described as the science of human duty. These ethics are therefore the measurement by which a human being is graded as being good, bad and evil. In simple terms moral ethics are nothing but the code of conduct decided by each person for himself or herself for operating in this world and fellow beings.

Moral ethics are formed from the obligations and duties of a person in the society. Nobody can force a person to adhere to moral ethics. For e.g. if a person sees an accident victim lying on the road it is his moral ethic to help out the victim but if he chooses to not do so then no social institution can punish him for this unwillingness. Thus these ethics are relative and subjective.

\subsection{Military Service}

The IAF is one of the world's largest military force, with roughly 1.32 million active standing army, with 2.14 million reserve forces and 1.3 million paramilitary forces thus giving India the third-largest active troops in the world as of 2006.

Armed force has two well defined roles. Its primary role is to defend the nation against external aggression and secondary role is to assist the civil administration in internal security duties and in times of calamities( Thapliyal,2011) Unfortunately in the last fifteen years or so, military involvement in Counter Insurgency Operations has increased manifold. There are incidents of fake killings to garner awards, violation of human 
rights incidents of rape and torture and an alarming increase in the tendency to go to civil courts to seek redress all this point to the fact that somewhere there is decrease in the value system of military personnel.

\section{$\underline{\text { 1.3Military \& Ethics }}$}

The most fundamental feature that distinguishes a soldier from his civilian counterpart is the soldier's unlimited commitment and liability, which may result in sacrifice of one's life. Ethics is concerned with life as it ought to be lived, entailing an unceasing struggle for self-improvement. Ethics has a special meaning to the profession of arms because it calls upon its members to make unreserved supreme sacrifice of life at the bidding of a superior in the hierarchy. Therefore, unless the man has firm faith in the ethical correctness of the superior's motive and conduct, he will lack conviction in his act and will avoid risks to his life and honour.

The Indian soldier has a heterogeneous social and cultural background, which in fact is a replica of Indian society and culture. The recruits come from different regions, linguistic background, castes, religion, class, and family background and differ in their process of pre-army socialization. It is significant to note that despite the heterogeneity of their background, the military system has superimposed upon them the uniformity and homogeneity of the military culture of routine work, duty and styles of life. This synthesis of a distinctive micro-level background and military macro level imposition has created national integration, something problematic amongst the civilian population.

The social background of the soldiers reveal differentiation and heterogeneity, yet the professional socialization of the personnel makes them share a similar sub-culture and behavioural patterns especially in relation to argot, dress, physical fitness and values of discipline, punctuality and loyalty. To transform heterogeneous categories into a homogenous community is the result of the military tradition as well as disciplined training. There is no large-scale organization which has such a primordial goal of serving the nation and thereby necessitating the supreme sacrifice of life itself when required. In fact, even the most primary institution of family does not ask for the sacrifice of life. It is only the defence where the members are prepared to sacrifice their life for the nation and its security. Thus the military reveals a high degree of organizational altruism, which is inculcated through well-organized mechanism of socialization, strict training and discipline. The inscription at the Chetwode Hall of Indian Military Academy, Dehradun, serves best to conclude this part. "The safety, honour and Welfare of your country comes first always and every time.

The honour, welfare and comfort of the men you command come next.

Your own ease, comfort and safety come last always and every time."

This is in short the true ethics of Indian Military Officer.

There is a requirement to accept that there has been a decline in the discipline, ethos, culture and ethics of the Military. There are two main reasons for this. First the Military personnel come from the same society where erosion in the value system is constantly taking place for various reasons. Consequently it is difficult for the personnel to remain completely immune to these corrupting influences. These can only be minimized by the training, culture, ethos, regimental system and traditions of the Army. These need to be preserved and nurtured at all costs.

Mark Twain had once said: Corruption is like weather. Every one knows about it but no one can do anything about it. But, sure, something can be done to protect ourselves from it as we can do something to protect ourselves from inclement weather. This something is to build public opinion for a clean and transparent government and refuse to cooperate with the corrupt.

In our relentless quest for success, recognition and even fame in an increasingly consumerist competitive world, the military also seems to have become obsessed with "Doing a Thing Right" rather than "Doing the Right Thing." Intense competition to climb the 'Pyramid', numerous environmental compulsions, and the desire for quick results in the face of complex pressures have possibly resulted in ethics, values and principles falling by the wayside. Media reports of stage-managed encounters and killing of terrorists and senior leaders looking toward civil courts for resolving promotion issues in India, human rights violations of prisoners by US military leaders, the tail-hook scandal, etc. are but indications of the broader decline from the proverbial tradition of an officer being a gentleman first who would lay down his life for a cause and principle.

The armed forces have lived and operated in isolation all these years, admired from a distance by both the common people and the political establishment. Ethical misdemeanours were more often than not viewed as mere aberrations and not systemic faults, and swept under the carpet after symbolic courts of enquiries or even court martial. Institutional concern was not very apparent as the overall quality of military leadership was considered to be very high and comparable to the best in the world. Things started changing in the Nineties because of both geopolitical and environmental changes.

In 2007, the defence circle was also being memorized as year of corruption. During the said year, two Lieutenant Generals, S.K. Dahiya and S.K. Sahni including two Major Generals, Anand Swaroop and SP Sinha were charged in separate cases of irregularities. Again in 2007, the CBI sorted out Major General Anand Kapoor for possessing disproportionate assets to the tune of rupees five crore. In another case, Major General Gur Iqbal 
Singh Multani was found guilty in smuggling of large quantities of defence liquor to his hometown. He was sentenced to rigorous imprisonment, stripped of his rank and dismissed from service by a military court. Nonetheless, almost every month, we see some odd case of corruption in the Indian armed forces, but involvement of the senior ranked army officers like Major Generals, Lieutenant Generals and full Generals in corruption cases is a matter of concern for the whole Indian Armed Force. It is due to this fact that over the years, the confidence of the soldiers over their military leadership has been dwindling because of their mallpractices, raping women, involvement in sex scandals, becoming party to land mafia groups and involvement in financial embezzlements.

The major factors that have accelerated the erosion of ethics and values in the Indian armed forces are:

- Rapid economic growth and growing disparity in income between the military and other professions

- Increased involvement of the armed forces in internal security duties without adequate institutionalised sensitisation.

- Increased involvement in anti-terrorist operations and the associated

- Dilemmas of force protection vs non-combatant immunity, collateral damage and civilian casualties.

- Enhanced civil military, para military liaison and increase in the exposure of men in uniform to various forms of corruption.

- Poor resettlement opportunities for officers and men who superannuate early in life.

- Changed priorities of the younger generation and absence of enough 'role models', coupled with reluctance on the part of senior officers to assume serious mentoring roles.

- Lack of any serious institutionalised training in ethics and value-based leadership for officers and men.

- Intense media scrutiny of matters relating to the military.

- Closed assessment system and absence of a fair in-house redressal system that forces military personnel to go to court and tarnish the self-image of the armed forces.

- Changing morality of personal relationships in society. ( Subramaniam,2006)

\section{Purpose}

The purpose of present research is to examine the issue of erosion of moral ethics among military personnel. The study also focused on the causes and the factors responsible for this erosion among the saviour of the nation.

\section{Hypothesis}

To obtain the purpose of the research following hypotheses were formulated:-

1. It is expected that the erosion of moral ethics will be observable in all branches of military service (Army, Air Force \& Navy).

2. It is expected that Military personnel will not discuss the issue of erosion of moral ethics officially.

3. It is expected that erosion of moral ethics will be more at senior level as compared to junior level.

\subsection{Sample}

\section{Method}

A sample of 60 military personnel was selected on the basis of incidental cum purposive sampling method. The division of sample is as follows:

\subsubsection{Sample Description}

Military Personnel N=60

\begin{tabular}{|c|c|c|c|}
\hline Branch & Total No. & Retired Officer & Serving Officer \\
\hline Indian Army & 20 & 10 & 10 \\
\hline Indian Air force & 20 & 10 & 10 \\
\hline Indian Navy & 20 & 10 & 10 \\
\hline Total & $\mathbf{6 0}$ & $\mathbf{3 0}$ & $\mathbf{3 0}$ \\
\hline
\end{tabular}

\subsection{Tool}

The data for present study is based on both primary and secondary sources. For primary sources researcher used a self prepared opinion based tool which consisted of 10 questions with three alternative answers. The respondent had to choose one answer from the three available options. The collection of data was also followed by a short interview with respondent on one to one basis. For secondary sources researcher used reports of electronic and print media. 


\section{Discussion \& Interpretation}

The analysis of result was done qualitatively. The hypotheses framed are discussed as follows:

Hypothesis 1: It is expected that the erosion of moral ethics will be observable in all branches of military service (Army, Air Force \& Navy).

It was hypothesised that the erosion of moral ethics will be in all the three branches of military services, namely Army, Air force \& Navy. The result also revealed the same as out of 60 personnel 52 felt that there is an erosion of ethics among military personnel. Almost $87 \%$ of the sample agreed with the fact that there is erosion of ethics among the military personnel. The branchwise specification of response is as follows in which out of 60 samples 52 responded that Charm of military service is diminishing due to degrading moral ethics among the military personnel.

Table 1Response of officers on agreement on erosion of moral ethics

\begin{tabular}{|c|c|c|c|}
\hline Branch & $\begin{array}{c}\text { Total No. of Officer (10 } \\
\text { Retired + 10 Serving Officer) }\end{array}$ & $\begin{array}{c}\text { Response of Retired } \\
\text { Officer }\end{array}$ & $\begin{array}{c}\text { Response of Serving } \\
\text { Officer }\end{array}$ \\
\hline Indian Army & 20 & 10 & 09 \\
\hline Indian Air force & 20 & 09 & 08 \\
\hline Indian Navy & 20 & 09 & 07 \\
\hline Total & & $\mathbf{2 8}$ & $\mathbf{2 4}$ \\
\hline
\end{tabular}

When researchers further clarify this point in order to get a clearer picture of the finding it was found that 52 respondents felt that there is erosion of ethics in the defence service. The remaining 08 respondent felt that there is no erosion of moral ethics among the defence personnel and they opined that it is only media created hype. Thus on the basis of result it can be said that there is erosion of ethics among military personnel. The cases like- Sukhna Land Scam, Adarsh Society Scam, Manorma Devi Rape case, A.K. Nanda Sex Scandal, Gorshkov Sex Scandal, Golf Cart Scandal, Dimple Singla Bribery Case, Ration Scam, Defence Recruitment Scandal, etc are few such case in past 3-4 years which is the clear indication of erosion of ethics in military service irrespective of their branch. The reasons given for this erosion was basically the corruption in the system and the hardship involved in the job as the ethics of most military forces generally mirror the ethics of the society that they are a part of. Thus the hypothesis has been proved that "The erosion of moral ethics will be in all branch of military service (Army, Air Force \& Navy)."

\section{Hypothesis 2: It is expected that Military personnel will not discuss the issue of erosion of moral ethics officially}

It was hypothesised that the personnel who are in service will not discuss the issue of erosion of moral ethics. A sample of 60 military personnel was targeted for this purpose which comprised of 30 retired personnel and 30 in service personnel of all the branch of military service (description given in sample section). It was found that out of 60 only 30 respondents who were retired military personnel responded to the questionnaire and gave time for the one to one interaction (interview) with researchers. The remaining 30 respondent who were in service kept themselves aloof from the study citing the reason that these are sensitive issues and officially they cannot comment or give their opinion on this topic. But all of them agreed with the point that there is erosion of moral ethics in defence service. The responses are shown below:

Table 2 Responses of the officers on Official discussion on "Erosion of moral ethics"

\begin{tabular}{|c|c|c|c|}
\hline $\begin{array}{c}\text { Branch of Military } \\
\text { Service }\end{array}$ & $\begin{array}{c}\text { Total No. of Officer (10 } \\
\text { Retired + 10 Serving } \\
\text { Officer) }\end{array}$ & $\begin{array}{c}\text { Response of Retired Officer } \\
\text { in favour of erosion of moral } \\
\text { ethics }\end{array}$ & $\begin{array}{c}\text { Response of Serving } \\
\text { Officer in favour of } \\
\text { erosion of moral ethics }\end{array}$ \\
\hline Indian Army & 20 & 10 & 0 \\
\hline Indian Air force & 20 & 10 & 0 \\
\hline Indian Navy & 20 & 10 & 0 \\
\hline Total & $\mathbf{6 0}$ & $\mathbf{3 0}$ & $\mathbf{0}$ \\
\hline
\end{tabular}

Thus on the basis of response of the sample it was concluded that the military personnel who are in service did not found themselves comfortable in discussing the issue of erosion of moral ethics. Hence their responses are nil on the issue. Thus the hypothesis formulated is being proved that "Military personnel will not discuss the issue of erosion of moral ethics officially."

Hypothesis 3: It is expected that erosion of moral ethics will be more at senior level as compared to junior level.

It has been hypothesised that the erosion of moral ethics will be more prevalent at senior level of the service. The researchers started their study with a sample size of 60 respondents but as mentioned earlier 30 respondents straightway showed disinterest in research and kept themselves away from the study. So the study 
at this stage was based on the response of only 30 respondents who were retired military personnel. Out of 30 respondents 26 of them said that the erosion of moral ethics is more at senior level, 03 respondents felt that the erosion of ethics is at middle level and only 01 respondent felt the erosion of ethics is at junior level. According to senior respondents the reason for this erosion of moral ethics is due to the hardship involved in the service and also because the pay and perks are not at par with the hardships involved. So for recognition and promotion officer in-charge influences his middle and junior level officer to indulge in unethical activities. It was also pointed that the corruption in society also influences the system as the ethics of most military forces generally mirror the ethics of the society that they are a part of. Some officers were of the view that initiative of unethical work is being proposed by the senior officer and the officer junior to him becomes a scapegoat. Cases like Ration Scam, Adarsh Society Scam, Golf Cart Scam, Sukhna Land Scam etc indicate that not only one officer is involved in it but many are associated with this unethical process. Not only people involved in defence service but political connectivity is also very common cause of such unethical behaviour. Approximately $94 \%$ of respondent at the time of interview said that they were attracted to other jobs at their middle of their service because of the fact that work pressure, hardship involved in work and also the officer in charge behaviour were not going hand in hand, and also the work done were not recognised or appraised as per the hardship involved. This is shown as follows:

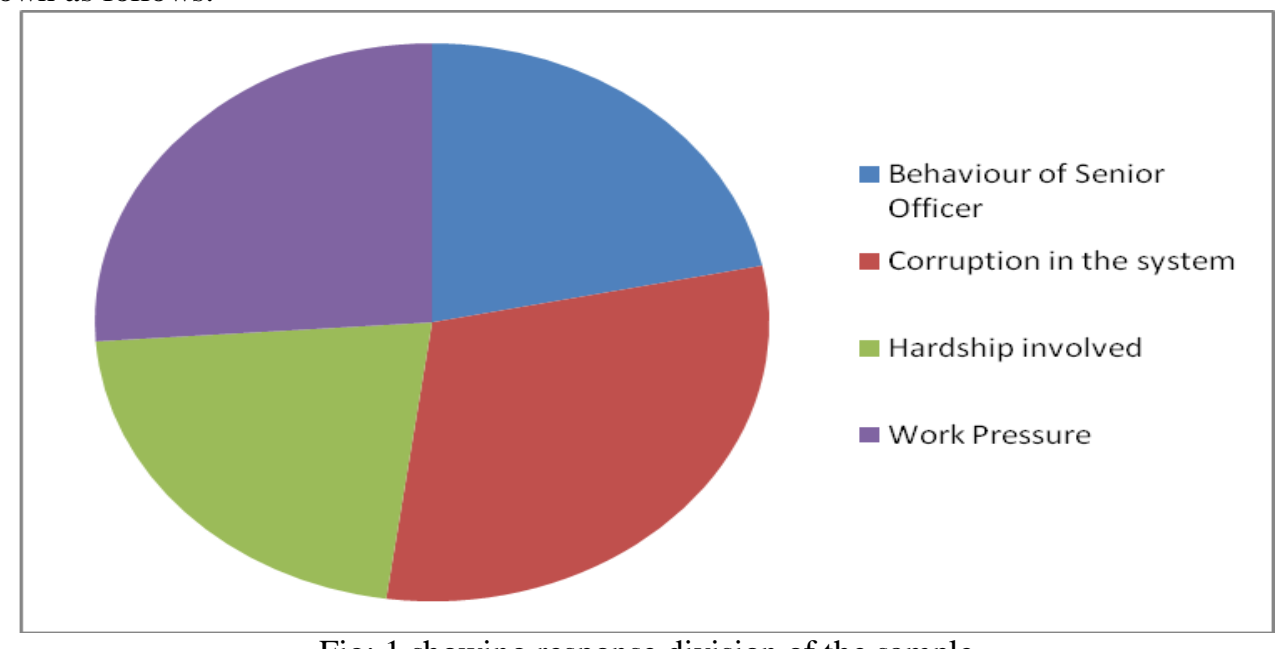

Fig: 1 showing response division of the sample

Thus it can be said that erosion of moral ethics is more prevalent at senior level as these officers become role-model for their subordinate. Hence hypothesis "Erosion of moral ethics will be more at senior level" is being proved.

\section{Conclusion}

On the basis of the study done it was found that the charm of military service is vanishing due to causes like more job opportunity and degrading ethical values of the servicemen. The respondent felt that the quality of servicemen is also deteriorating day by day because of the fact that the creamy layer of students opt for civil servant job as they consider it to be a white collar job and also it offer a good and secure life along with a very good pay and perks with minimum hardship. Younger generation also go for job in MNC and other private sector as the hardship involved is very less along with a comfortable work life. Thus the priority of job for younger generation has changed. Now a day career in defence is kept at low priority list. On the basis of studies the researchers concluded that there are many causes or factors responsible for erosion of moral ethics among military personnel like Corruption in system, Hardship in work, tremendous work pressure and absence of reward and recognition at all level of work life. At the time of the interview it was noticed that defence personnel felt that there contribution is being neglected by the society as society gives upper hand to civil servants and ignored hard work and sacrifices which a soldier offer. Thus on concluding note it can be said that the ethics of military forces generally mirror the ethics of the society that they are a part of and for making a strong ethical based system first and foremost the society need to be restructured.

\section{Suggestions}

Actions of a few senior officers should not tarnish the image of the entire military-which still largely adheres to the ideals of honour, service and patriotism. There are steps that can be taken to uphold the image of the military. Researchers have put forward some suggestions which they felt can contribute in rebuilding of moral ethics among the military personnel. Those are as follows:

- Senior officers have to enact a code of conduct for themselves, just like the one they impose on soldiers serving in the field. This should focus on ethical, financial and professional issues. For instance: 
- Senior officers should resist accepting, at least for a period of two years, post-retirement jobs that are a potential conflict of interest. This includes government-appointed positions like governors, or executive positions in public and private sector units. Instead, they should accept positions related either to education or philanthropy like welfare for ex-servicemen or war widows.

- Policies and norms should be formulated to guard against parochial interests and ad-hoc, personality- driven policy making which divides the officer class.

- To adopt a bottom-up approach in inculcating ethics and values in both officers and other ranks.

- Along with military history, ethics and values education must be included in the curriculum.

- Study of ethics and values should be from an even younger age at Sainik schools and institutions as part of a character building and training programme.

- Resettlement and parallel absorption in the public and private sectors of retired officers and men, or veterans as they are now called, is vital in keeping relatively young military leaders secure about their future.

Mentoring in the armed forces is becoming a lost art that has to be revived if we are to pass on ethics, values and traditions to the younger generation. Many middle ranking and senior officers are, at times, so busy furthering their own careers that they see little value in investing time and intellect on the younger generation, who in turn are getting used to 'quick fix' solutions and increasingly reluctant to take the difficult path of doing the 'right thing'. So, the Mantra should be to catch them young and inculcate in them the ability to quickly differentiate between right and wrong so that when the going gets tough, a military leader seldom takes the easy way out.

Ethics are never dispensable. They are an integral part of human survival. But in the 21st century, such survival will be more complicated and precarious than ever before, and the ethics required of us must be correspondingly sophisticated. Finally, ethics are absolutely necessary to tackle the pressure of truth, occupy the moral high ground and reinforce the position of the military as the vanguard of a nation's leadership.

If it is not right, do not do it.

If it is not true, do not say it.

- General Marcus Aurelius

Roman General

During a recent survey the image of the Armed Forces proved to be the highest among the governmental institutions. We all should maintain this standard as the military structure of the country is heart of the nation and the values and ethics forms a core component of a system.

\section{References}

[1]. Chinamayananda,Swami(1975).The Holy Gita.Bombay:Central Chinmaya Trust.

[2]. Chaplain (Col) Samuel D. Maloney, "Ethics Theory for the Military Professional," Air University Review 32 , no. 3 (March-April 1981): 63-71

[3]. Parmar,L.( 2008).Ehics and Indian armed from http://www.bmlv.gv.at/pdf_pool/publikationen/08_cma_06_par.pdf

[4]. Thapliyal,S.( 2011). Army: A need for introspection.Net Edition: Indian Defence Review

[5]. Cook, M. L. and Syse, H.(2010)'What Should We Mean by 'Military Ethics'?'.Journal of Military Ethics, 9:2, 119 - 122

[6]. Padmanabhan,S. (2006)."The Indian Army in 2020”, Security research review, Journal of Bharat Rakshak.com, Vol 2,2

[7]. Subramaniam, A (2006)..Ethics and Values in Military Leadership. Air Power Journal Vol. 3 No. 2176

[8]. (2011, 01). Ethical and Moral Issues. StudyMode.com. Retrieved 01, 2011, from http://www.studymode.com/essays/Ethical-AndMoral-Issues-555983.html 